\title{
居住状態における住宅室内の揮発性有機化合物に関する実態調査 FIELD STUDY ON VOLATILE ORGANIC COMPOUNDS IN RESIDENCES
}

\author{
熊谷一清*1, 池田耕一*2, 堀 雅 宏*3, 松村 年 郎*4 \\ 野㟝淳夫*5, 木村 洋*6, 飯 倉一雄*7, 吉澤 晋*8 \\ Kazukiyo KUMAGAI, Koichi IKEDA, Masahiro HORI, Toshiro MATSUMURA, \\ Atsuo NOZAKI, Hiroshi KIMURA, Kazuo IIKURA and Susumu YOSHIZAWA
}

\begin{abstract}
Recently in Japan, high concentration of VOC caused by air-tightness in residences has become a social problem. There are many chamber tests of individual materials or measurements taken place in experimental residences. In real residences there are occupants. There is a possibility of them taking in sources of VOC, changing environmental conditions and etc., which will effect on the emission of VOC inside the residences. In this study we measured VOC concentration including formaldehyde in 50 residences. As a result, the mean concentration of $\mathrm{HCHO}$ and TVOC were $0.0478 \mathrm{ppm}$ and $3640 \mu \mathrm{g} / \mathrm{m}^{3}$ and the standard deviation were $0.0415 \mathrm{ppm}$ and $8240 \mu \mathrm{g} / \mathrm{m}^{3}$. The concentration differed 1.7 times with HCHO and 15 times with TVOC between new and old residences. In both HCHO and TVOC concentrations were higher in the winter time. There were no correlations between the temperature or relative humidity and the concentrations of $\mathrm{HCHO}$ or TVOC. The HCHO concentration became steady in about 6 years and TVOC concentration in about 8 years. Also it is neccessary to be aware of the product which the occupants bring inside the residences.
\end{abstract}

Keywords: volatile organic compounds, residence, field measurement 揮発性有機化合物、住宅、実測調查

\section{1. はじめに}

近年、住宅の省エネルギー化に伴い室内の高気密・高断熱化された 住宅が一般的になってきている。一方、建材や仕上げ材、生活用品等 の生産技術の進歩により、在来みられなかった新しいタイプの建材等 が、室内に導入されはじめており、それらから発生する揮発性有機化 合物 (以下VOC)による化学物質過敏症などに代表される健康あるいは 生理影響が報告されている。これに対し室内での発生量の抑制、換 気、ベイクアウト等の建築的な対策が要求されている。しかし、住宅 内の実状を示す基礎データが十分とはいえず、生活が営まれている住 宅でのデータの収集が早急な課題である。

海外での報告として、Krauseはドイツ連邦共和国の500軒の住宅を 対象に測定を行った結果、総揮発性有機化合物（以下、TVOC）潾 度は平均值 $394 \mu \mathrm{g} / \mathrm{m}^{3}, 50$ パーセンタイル $312 \mu \mathrm{g} / \mathrm{m}^{3}, 90$ パーセンタイル $665 \mu \mathrm{g} / \mathrm{m}^{3}$ であり檂度の範囲は72-2670 $\mathrm{gg} / \mathrm{m}^{3}$ であり"、 $\mathrm{n}$-アルケン属が TVOC濃度の指標物質として有効であると報告している。0tsonはカナ ダの 757 件の住宅を対象とした調査ではETS、家庭用品、プラスチッ ク製品が 室内のV O C に影響を与えている4)としている。また、 Seifer $\mathrm{t}^{6)}$ 、Wolkof $\mathrm{f}^{\mathrm{B})}$ は室内VOC濃度は居住者の活動に大きく左右され ると報告している。さらに、Wallaceは米国の 5 つの都市の 600 軒の
住宅を対象にVOCの測定を行っており、喫煙、熱湯、ドライクリーニ ングが行われた衣類や防虫剤が居住状態におけるVOCの主な発生源と している。また、室内濃度を屋外濃度で除したI/0值はいずも 1 より 大きく、VOC は多くの場合室内由来である ${ }^{9)}$ と報告している。

国内の住宅でのホルムアルデヒド(以下HCHO) とVOC報告としては、 Park が筑 5-35 年の 11 戸5)、坂本が鹿児島市内の木造住宅 17 住戸 ${ }^{14)}$ 、 豊住が生活状態の 11 住戸 ${ }^{16)}$ 、宮崎がリフォーム前後の 3 住戸 ${ }^{20)}$ 、守

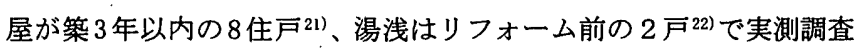
を行っている。その結果、多くの報告で同定された物質のI/0值がい ずれも 1 より高く、またキシレン、トルエン等の溶剤系の物質と防虫 片に使用される $\mathrm{p}$-ジクロロベンゼン浱度が高いことが指摘されてい る。それ以外の住宅に関する報告では、環境因子が制御された実験住 宅における測定例が多く、その測定対象物質として HCHO のみを測定 している報告が殆どである。しかし、いずれにおいても居住者により 様々な化学物質が持ち込まれることが予想される生活状態における住 宅内のHCHO、VOCの濃度分布や環境因子による影響についてその実態 を報告したは文献は少ない。

そこで、本研究では実際に人が住んでいる住宅を対象とし HCHO と VOC32物質について測定を行い、季節変動、住宅種別の関連要因につ

\footnotetext{
*1 国立公䌽衛生院建築衛生学部 研究課程生・工修·公衛修 Ph. D. Student, Dept. of Architectural Hygiene Engineering and Housing,

*2 国立公衆衛生院建築衛生学部 部長・工博

*3 横浜国立大学教育人間科学部 助教授 $\cdot$ 工博

*4 国立医薬品食品衛生研究所 室長·工博

*5 日本大学東北高等学校建築科 教諭. 工博

*6 長谷エコーポレーション技術研究所 研究直

*7 国立公衆衛生院建築衛生学部 専門課程生

*8 東京理科大学工学部建築学科 教授. 工博 The Institute of Public Health, M. Eng., M. P. H.

Director, Dept. of Architectural Hygiene Engineering and Housing, The Institute of Public Health, Dr. Eng.

Assoc. Prof., Faculty of Education and Human Sciences, National University of Yokohama, Dr. Eng.

Head, Division of Environmental Chemestry, National Institute of Health Science, Dr. Eng.

Lecturer, Dept. of Architecture, Nihon University Tohoku High School, Dr. Eng. Research Engineer, Haseko Research Institute, Haseko Corporation

Master Student, Dept. of Architectural Hygiene Engineering and Housing, The Institute of Public Health

Prof., Dept. of Architecture, Science University of Tokyo, Dr. Eng., M. Sc.
} 
いて検討したのでここに報告する。

\section{2. 湘定。分新裙票}

\section{1 測定時简}

本研究は 1996 年 3 月に冬期、同年の 8 月に夏期の測定を行ってい る。冬期の測定時期については、春期にずれ込んでいるともいえる が、生活中の然焼器具の使用頻度、空開け状況の検討より、冬期時の 生活と相違ないことよりこの時期を冬期時の測定とした。

\section{2 測定的隍}

測定対象住宅は郡山 (福島県) と首都圈に建つ戸建住宅及び集合住 宅の全 50 戸の住宅である。住宅の分類として冬期の測定開始時に築 後半年以内の住宅を“新築住宅”(35戸)、6ヶ月以上経っている住宅を “既築住宅”(15戸) とした。また、住宅の工法としては在来工法、工 業化住宅及び鉄筋コンクリート造の集合住宅に分類した。さらに、首 都圈の集合住宅では、住宅を入居前および入居後とした（表 1)。な お、同一の住宅で冬期と夏期の両方で測定を行ったものについては冬 期の測定開始時に築 6 ケ月の前後で分類している。また、後の築年数 と浱度との比較では䇋工後の年月により処理を行った。

\section{3 測定方济}

各住宅において、HCHO、VOC、温度、湿度の測定を行った。サンプ リング、温湿度は居間の中央部の床面より高さ $1.2 \mathrm{~m}$ の位置で測定し た。

入居前の住宅では、測定開始前の 30 分間空を開け換気を行い、そ の後開口部を密閉し測定を開始した。また、サンプリングを行う前 に、入居前の住宅では屋外に通じる開口部、換気口を全て閉じ、室内 の間仕切り建具は開放した状態で測定を行った。

入居後の測定では、通常の生活状態の曝露量を把握するため、入居 者による換気、喫煙、空明けは通常の生活通りとし、アンケート調査 により空明け換気時間や喫煙本数、暖房器具の使用状況の把握を試み た。

\section{䇝 1 測定封缐住宝}

\begin{tabular}{|c|c|c|c|c|c|}
\hline 住宅の新旧 & 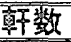 & 工流 & 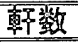 & 入詹の有慜 & 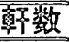 \\
\hline \multirow{3}{*}{ 新笺 (郡山) } & 10 & 注来工法 & 10 & & \\
\hline & & 工蔹化住完 & 0 & & \\
\hline & & 䉇合住宅(RC造) & 0 & & \\
\hline \multirow[t]{3}{*}{ 衙经(首暗圈) } & 25 & 彺来工泫 & 3 & & \\
\hline & & 工鄴化住宅 & 6 & & \\
\hline & & 䇣合住宅(RC造) & 16 & 入居前 & 5 \\
\hline \multirow{3}{*}{ 槩築(郡山) } & 8 & 在㠫工法 & 7 & & \\
\hline & & 工鄴化住宅 & 1 & & \\
\hline & & 䇺合住宅(RC造) & 0 & & \\
\hline \multirow[t]{3}{*}{ 既筑(首暗图) } & 7 & 在桨工法 & 0 & & \\
\hline & & 工積化住宅 & 3 & & \\
\hline & & 筑合住宅(RC造) & 4 & & \\
\hline 合計 & 50 & & 50 & & \\
\hline
\end{tabular}

\section{3. 1 HCHO の測定}

本研究ではパッシブサンプラーと、USEPA（米国環境保護庁）で採 用されているDNPH-カートリッジポンプ吸引法 ${ }^{10} に よ り 24$ 時間平均蔇 度を求めた。以下では、その詳細について述べる。

\subsection{1.a パッシブゲンプラーによるHCHO の測定 ${ }^{12)}$}

(i) ケัンプリンク゚法

HCHOのサンプリングはパッシブサンプラー法を用い、サンプリング
時間を 24 時間としサンプルの捕集を行い、その後アルミ製保存袋に 入れ冷暗な環境下で保管しサンプル試料とした。

(2) 㟧隄界

本研究で用いたパッシブサンプラーの検出限界 ${ }^{23)}$ を検量線の最小読 み取り吸光度より求めた。その結果、24時間サンプリングで $0.005 \mathrm{ppm}$ となった。パッシブサンプラーの測定精度を検討するため、HCHO濃度 $0.05 \mathrm{ppm}$ のチャンバー内に本サンプラーを設置し、24時間サンプリン グ後の測定を行った結果、パッシブサンプラーでの HCHO の捕集量の 変動係数 ${ }^{23)}$ は 8.9\% であった。

(3) 定是缧作

パッシブサンプラーより捕集した試料空気は以下の手順で定量を 行った。パッシブサンプラーより捕集剤を取り出し、 $25 \mathrm{~mL}$ の共栓試験 管に入れ、これに純水 $15 \mathrm{~mL}$ を加えて軽く栓をし、60年の温水浴中で 15 分間加温する。室温に放冷、浸とう後、その上澄み液を遠心分離器 に移し、 3000 回転 $/ 5 \mathrm{~min}$ で遠心分離した。この上澄み液を分析用溶液 とし、その $2 \mathrm{~mL}$ を $20 \mathrm{~mL}$ の共栓試験管に取り、これに $2 \mathrm{~mL} の 5 \mathrm{~N}$ 水酸化

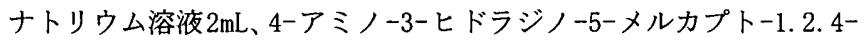
トリアゾール溶液 (AHMT) $2 \mathrm{~mL}$ を加え混合後、室温に 20 分間放置し、過 ヨウ素酸カリウム溶液 $2 \mathrm{~mL}$ を加え、軽く栓をし混合する。そして、10 分後に波長 $550 \mathrm{~nm}$ で吸光度 $(10 \mathrm{~mm}$ セル) を測定する。さらに、未使用 サンプラーについては同様の操作を行い、ブランクとし検量線を引き 漉度を(1) 式より算出した。

$$
\begin{aligned}
& C=(W \times 7.5) /(6.7 \times t) \cdots \cdot(1) \\
& \mathrm{C}=\mathrm{HCHO} \text { 室内湄度 }(\mathrm{ppm}) \\
& W=\text { 検量線から求めた } \mathrm{HCHO} \text { 重量 }(\mu \mathrm{g}) \\
& 7.5=\text { 希釈係数 } \\
& \text { 6. } 7=\text { 比例定数 }(\mu \mathrm{g} / \mathrm{ppm} \cdot \mathrm{h}) \\
& \mathrm{t}=\text { サンプリング時間 }(\mathrm{h})
\end{aligned}
$$

\section{3. 1.b DNPHー方ートリッシ゚ポンプ济}

DNPH-カートリッジは捕集剤に長さ $30 \mathrm{~mm} 、 2 \mathrm{~g}$ の DNPH含浸シ リカゲル 700mg 充填されたロングタイプ(Waters社製)を使用した。 (1)サンンプリンク゚济

試料の採取法とし、市販の DNPH含浸カートリッジを小型吸引ポ ンプに接続し、 $100 \mathrm{~mL} / \mathrm{min}$ の流速で 24 時間試料空気を捕集した。サ ンプリング終了後カートリッジをアルミ製保存袋に入れ、冷暗な場所 に保管し分析試料とした。

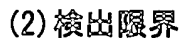

採取試料時間及び検出下限值(10s)から本法の検出下限濃度を算出 した結果、 24 時間サンプリングで $0.0003 \mathrm{ppm} 、 8$ 時間で $0.01 \mathrm{ppm}$ 、変 動係数は $3.1 \%$ であった。

\section{(3) 定已缲作}

DNPH-カートリッジにシリンジを取り付け（サンプリングロとは 反対側）バックフラシュの原理により操作した。これにアセトリニト リル 10mLを入れ、ゆっくり押し出し、カートリッジに捕集された誘 導体を溶出し、分析試料とした。分析試料溶液 $20 \mu \mathrm{L}$ 、高速液体ク口 マトグラフィーに導入し分析した。なお、ブランクには未使用のカー トリッジについて同様の操作により求めた。源度の算出は (2) 式に よる。また、表 2 に高速液体クロマトグラフの分析条件を示す。

$\mathrm{C}=\mathrm{v} \times(273+\mathrm{t}) / 273 \times 1 / \mathrm{V} \cdots \cdots(2)$ $\mathrm{C}=\mathrm{HCHO}$ 室内濃度 $(\mathrm{ppm})$ $\mathrm{v}=$ 検量線から求めた $\mathrm{HCHO}$ の体積 $(\mu \mathrm{L})$ 
$\mathrm{t}=$ 室温 $\left({ }^{\circ} \mathrm{C}\right)$

$\mathrm{V}=$ 試料空気の採取 $(\mathrm{L})$

表 2 高速液体クロマトグラフ分析条件

\begin{tabular}{lc} 
高速液体クロマトグラフ & 島津製 LC-5A \\
ガードカラム & Simpack G-ODS $(4 \mathrm{~mm} \times 1 \mathrm{~cm})$ \\
分析カラム & Simpack GL-ODS $(6 \mathrm{~mm} \times 15 \mathrm{~cm})$ \\
恒温槽 & $40^{\circ} \mathrm{C}$ \\
流量 & $1.3 \mathrm{ml} / \mathrm{min}$ \\
移動層 & アセトニトリル:水 $(60: 40)$ \\
注入量 & $20 \mu \mathrm{L}$ \\
測定波長 & $360 \mathrm{~nm}$ \\
\hline
\end{tabular}

\subsection{1.c パッシブサンプラーと}

DNPH-カートリッジ法との比較

本研究で用いたパッシブサンプラー法とUSEPA で採用されている DNPH-カートリッジポンプ吸引法との比較を同時測定により行った

(図 1)。その結果両者の間には $\mathrm{r}=0.96$ と高い相関が認められた。

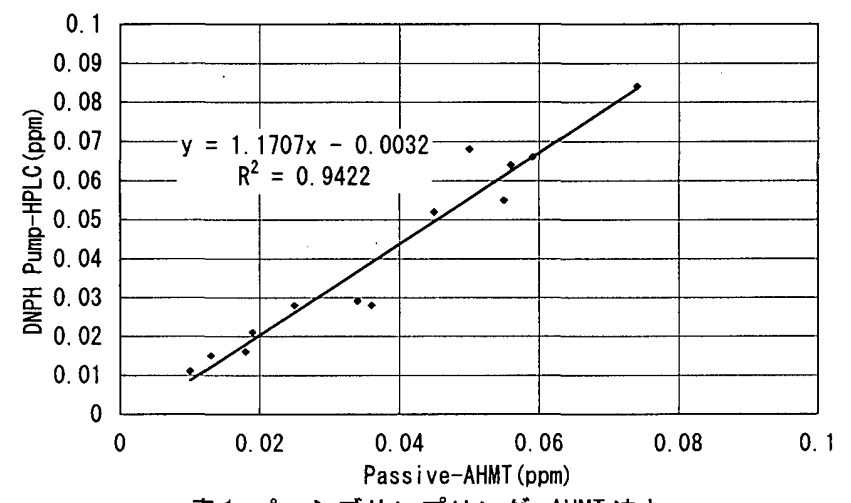

表 1 パッシブサンプリング-AHMT 法と

DNPHカートリッジーポンプ-HPLC法の相関

\section{3.2 VOC の測定 ${ }^{18)}$}

\section{(1) サンプリング法}

作業環境測定用活性炭捕集㓮(20〜40メッシュの活性炭を150ま たは200mg 充填したもの) と吸引ポンプ、ロタメータを接続し、200〜 $300 \mathrm{~mL} / \mathrm{min}$ の流量で $20 \sim 24$ 時間、 $180 \mathrm{~L}$ 以上通気した。終了後、両端 を栓で密閉しさらにアルミパックに入れ密閉後、冷暗場所にて保存し た。

\section{(2) 定量操作}

捕集管から活性炭を $2 \mathrm{~mL}$ のバイアル瓶にあけ、二硫化炭素を $1 \mathrm{~mL}$ 入れ栓をし、2 分間振とうし、3 時間放置する。上澄み液を $2 \mu \mathrm{L}$ マイ クロシリンジでガスクロマトグラフにかける。同様の操作を未使用の 活性炭管についても行ない、ブランク值とする。標準は予想される化 合物の純度 $98 \%$ 以上の液体を等量混合したものをメタノールで $0.1 \%(\mathrm{~V} / \mathrm{V})$ 溶液とし、さらに二硫化炭素で100倍に希採したものを用 いる。各成分の濃度は $(3)$ 式より算出した。

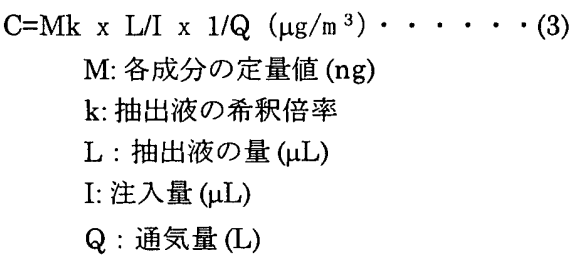

未同定成分はそのピークの和をn一へキサンに換算した。TVOC ${ }^{23) 77}$ は ガスクロマトグラムのピークの総面積を $\mathrm{n}$ 一ヘキサンに換算し重量濃 度を求めた。
表 3 ガスクロマトグラフ分析条件

\begin{tabular}{|c|c|}
\hline \multicolumn{2}{|c|}{ 装置 $\quad$ GLサイエンス製 GC-325 } \\
\hline \multicolumn{2}{|c|}{ キャピラリー・カラム $\quad c p-$ sil $0.5 \mathrm{~mm} \times 100 \mathrm{~m}$} \\
\hline \multicolumn{2}{|c|}{$\begin{array}{ll}\text { カラム温度 } & 40^{\circ} \mathrm{C} \rightarrow\left(10^{\circ} \mathrm{C} / \mathrm{min}\right) \rightarrow 100^{\circ} \mathrm{C} \rightarrow\left(3^{\circ} \mathrm{C} / \mathrm{min}\right) \\
& \rightarrow 180^{\circ} \mathrm{C} \rightarrow\left(10^{\circ} \mathrm{C} / \mathrm{min}\right) \rightarrow 230^{\circ} \mathrm{C}\end{array}$} \\
\hline \multicolumn{2}{|r|}{$18 \mathrm{~mL} / \mathrm{min}$} \\
\hline \multicolumn{2}{|l|}{ スプリット比 } \\
\hline \multicolumn{2}{|l|}{ 検出器 } \\
\hline \multicolumn{2}{|r|}{ 表 4 VOC 同定物質 } \\
\hline 脂肪族炭化水素類 & 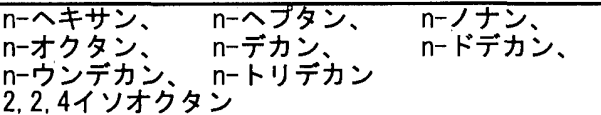 \\
\hline 芳香族崖化水素類 & 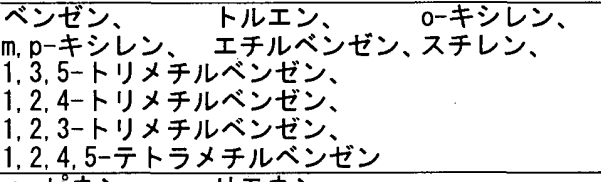 \\
\hline テルペン類 & 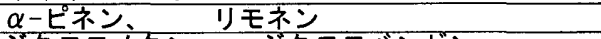 \\
\hline ハロゲン類 & $\begin{array}{l}\text { ジクロロメタン、p-ジクロロベンゼン、 } \\
\text { トリクロロエチレン、 }\end{array}$ \\
\hline エステル類 & 酢酸エチル、酢酸ブチル \\
\hline ケトン類 & $\begin{array}{l}\text { アセトンシ メチルエチルケトン. } \\
\text { メチルイン゙チルケトン }\end{array}$ \\
\hline アルコール類 & 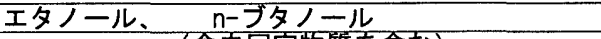 \\
\hline その他 & (含未同定物質を含む) \\
\hline
\end{tabular}

\section{3. 結果及び考察}

\section{1 全体（新築、既築、集合住宅）の測定結果}

全住宅のパーセンタイルを片対数で表すと HCHO、TVOCのいずれに おいても、S字の分布傾向を示していることにより対数正規分布であ る事が分かる（図 2、図 3)。HCHO、TVOCの濃度の統計值、パーセンタ イルに対する HCHO、TVOC の濃度を図 2、図 3 に示す。 $\mathrm{HCHO}$ 濃度の平 均值 $0.0478(\mathrm{ppm}) 、$ 中央值 $0.039(\mathrm{ppm}) 、$ 標準偏差が $0.0415(\mathrm{ppm})$ であ ることからばらつきが大きいといえる。また、TVOC 濃度の平均值は

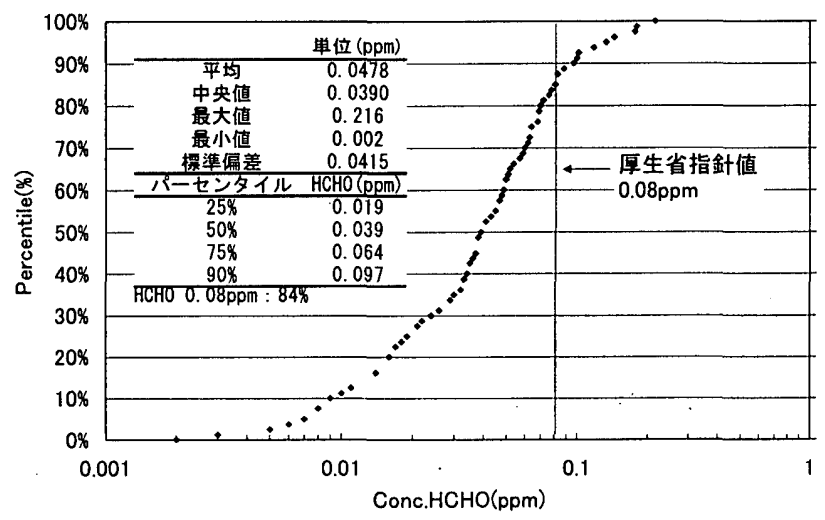

図 $2 \mathrm{HCHO}$ 濃度パーセンタイル

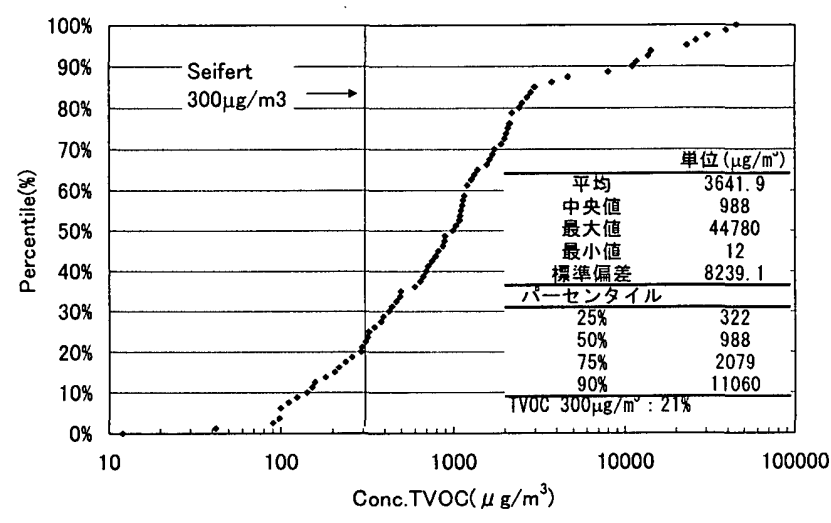

図3TVOC 濃度パーセンタイル 


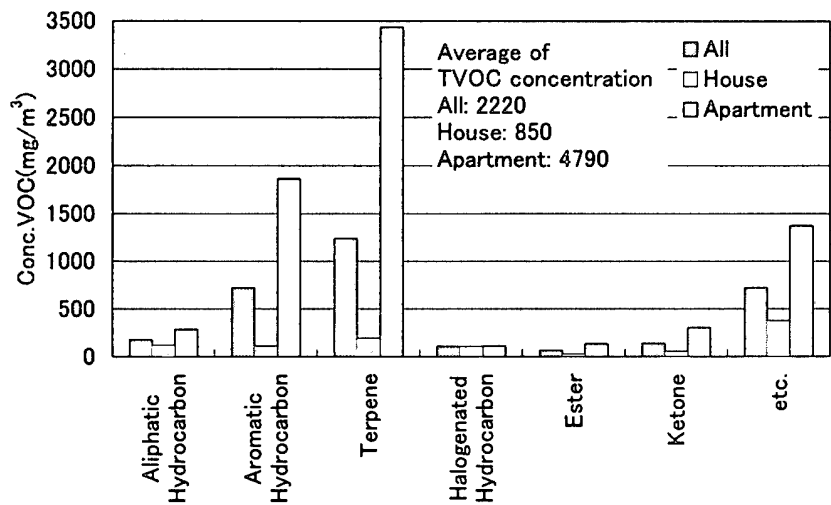

図 4 VOC 属別港度

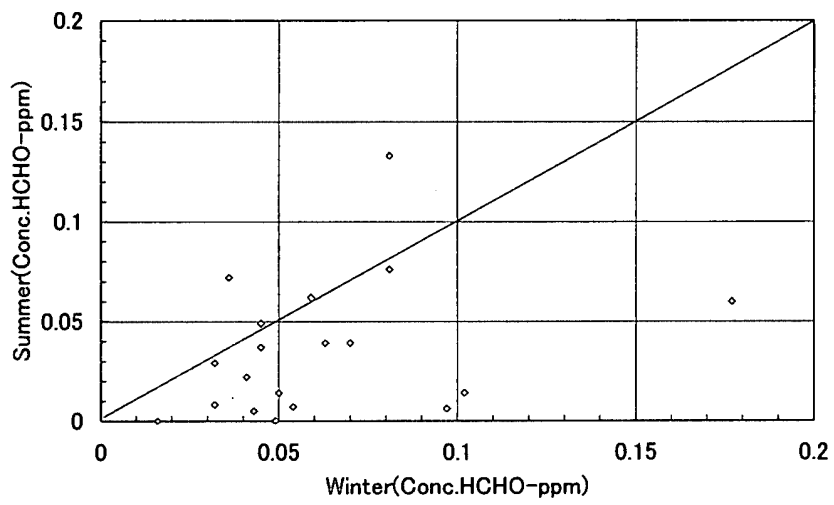

图 5 戸建 新築住宅における $\mathrm{HCHO}$ 搌度

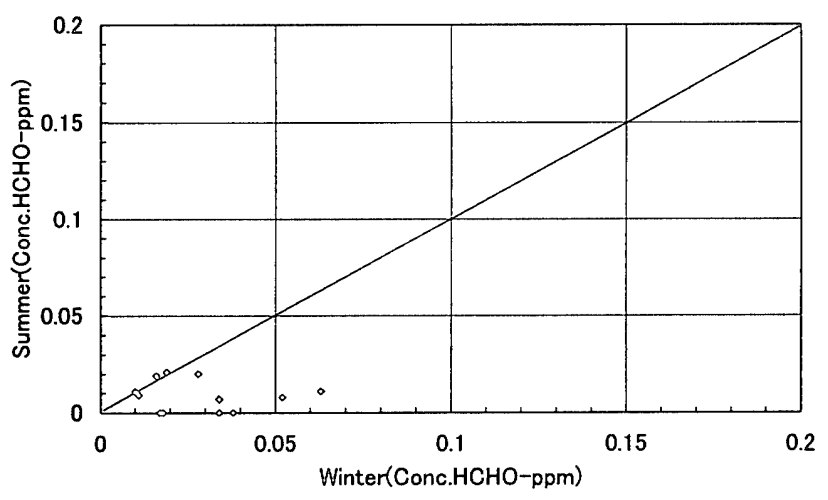

图 6 户建 既築住宅におけるHCHO莀虔

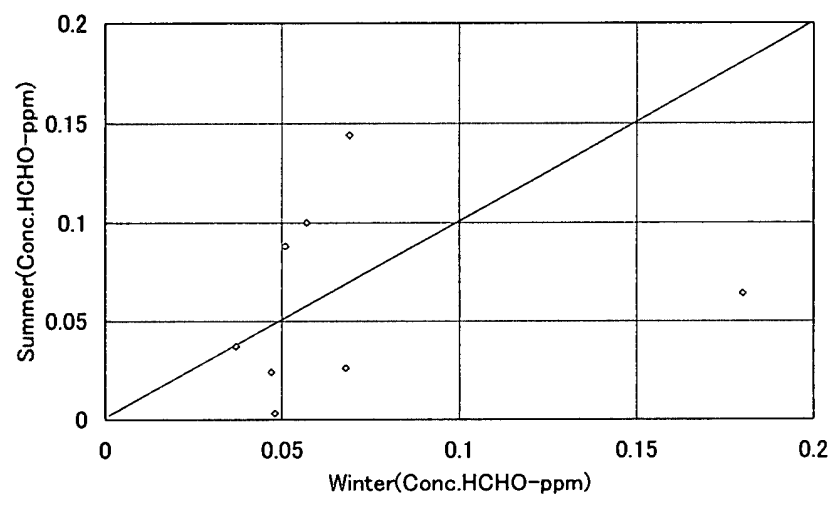

图 7 集合新築住宅におけるHCHO 浱度

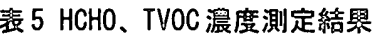

Conc.HCHO(ppm) Conc.TVOC $\left(\mu \mathrm{g} / \mathrm{m}^{3}\right)$

终期 夏期 年平均 终期 夏期 年平均

\begin{tabular}{|c|c|c|c|c|c|c|}
\hline 新筑戸建 & 0.062 & 0.040 & 0.051 & 1490 & 430 & 430 \\
\hline 既築戸延 & 0.028 & 0.01 & 0.022 & 1650 & 320 & 320 \\
\hline 全戸犍 & 0.049 & 0.030 & 0.040 & 1550 & 400 & 400 \\
\hline 新築箩合 & 0.068 & 0.066 & 0.067 & 14340 & 5920 & 10320 \\
\hline 既築集合 & 0.049 & - & 0.049 & 420 & - & 420 \\
\hline 全篹合 & 0.064 & 0.066 & 0.065 & 10860 & 5920 & 8850 \\
\hline 全住氞 & 0.054 & 0.040 & 0.048 & 4790 & 2130 & \\
\hline
\end{tabular}

企住它 $0.0540 .040 \quad 0.048 \quad 4790 \quad 2130$

\begin{tabular}{|c|c|c|}
\hline & $\mathrm{HCHO}$ (ppm) & $\operatorname{TVOC}\left(\mu \mathrm{g} / \mathrm{m}^{3}\right)$ \\
\hline 在巫工法 & 0.039 & 923 \\
\hline 工業化住宅 & 0.048 & 1339 \\
\hline 鏃筋コンクリート & 0.065 & 8849 \\
\hline
\end{tabular}

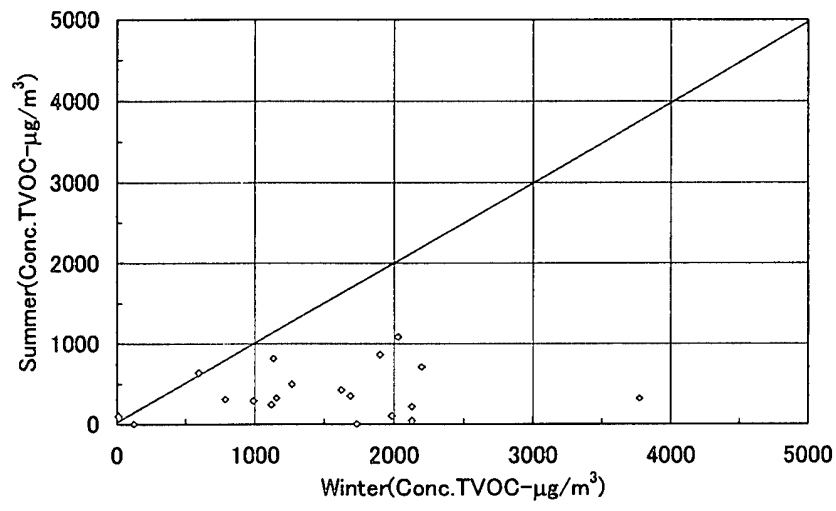

图 8 戸建新築住宅におけるTVOC 浱度

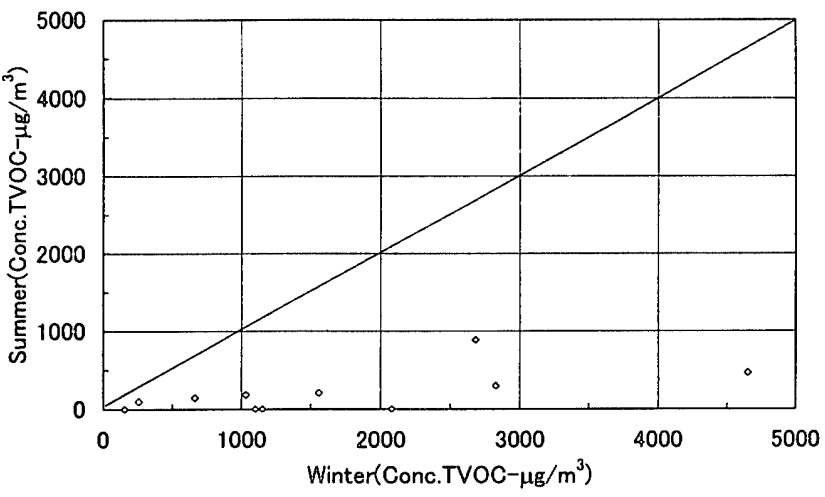

图 9 戸建既築住宅におけるTVOC 浱度

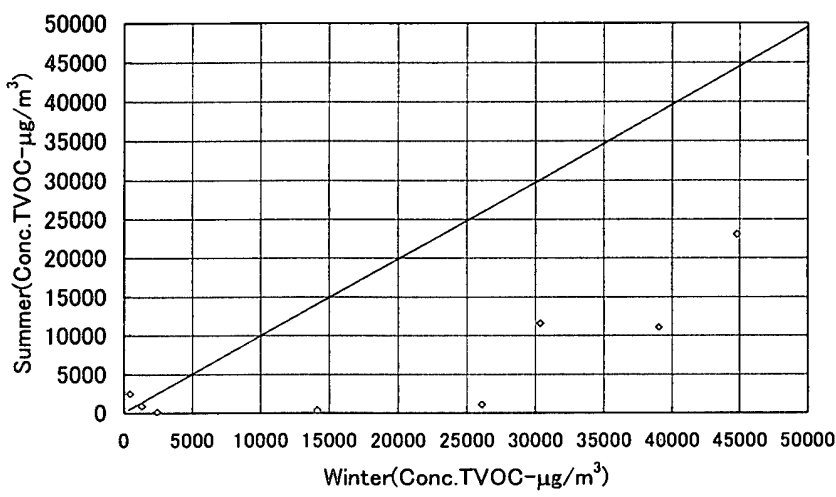

图 10 管合新築住宅におけるTVOC濃度 
$3640\left(\mu \mathrm{g} / \mathrm{m}^{3}\right)$ 、中央值 $980\left(\mu \mathrm{g} / \mathrm{m}^{3}\right)$ であり、標準偏差は $8240\left(\mu \mathrm{g} / \mathrm{m}^{3}\right)$ で ありTVOC 濃度もばらつきが大きい結果となった。

これを、厚生省が掲げるHCHO濃度指針值の $0.08 \mathrm{ppm}^{24)}$ と比較すると これを満す住戸は84\%であるのに対し、Seifertが提案するTVOC濃度 の推奖值 $300 \mu \mathrm{g} / \mathrm{m}^{37)}$ を満たしている住戸は $21 \%$ ありり、日本の住宅で はTVOC濃度の目標値の達成率が低いといえる。VOCを化学種別に検討 寸ると、芳香族炭化水素及びテルペン類で半分程度が占められてい る。芳香族炭化水素ではトルエンが多く、フローリング等用接着剤に 含まれる有機溶剛が発生源として考えられる。また、テルペン類では $\alpha$-ピネンの高い住戸が多い。 $\alpha$-ピネンは植物性の有機化合物であ り、天然材から揮発していると考えられる。

\section{2 住宅種別による比較}

$\mathrm{HCHO}$ 濃度平均值は、新築、既築の両方を含んだ戸建、集合住宅のい ずれの住宅種別においても厚生省の指針値の0.08 $\mathrm{ppm}^{24}$ 以下であった。 新築と既築の值を比較すると戸建では、既勧になると $58 \% \mathrm{HCHO}$ 濃度が 減少している。これに対し、集合住宅では夏期データがとれなかった ため冬期結果のみについて検討すると新築と既筑とでは40\%HCHO濃度 が堿少する結果となった。また、濃度分布より、新築住宅の分布幅は 広く、新築住宅で使用されている建材からの HCHOの放散が影響して いると考えられる。それに対し、既築住宅では生活による HCHO 放散 15)17)が影響していると考えられる。

TVOC 滶度について、戸建住宅での新築と既築の比は 0.75 であるの に対し、集合住宅ではその比が 0.04、つまり既築になると新築時の 96\%のTVOCが減少する結果となった。しかし、既築の戸建住宅と集合 住宅を比較するとその差は29\%であり、既築住宅になると住宅種別に よるTVOC 濃度にあまり差が生じないと言える。

ここでVOC を化学種別毎に比較すると（図 4 参照)、全住宅では木 材起因のテルペン類が最も多く、続いて接着郕、塗料に多く含まれる 芳香族炭化水素、脂肪族炭化水素の順になっている。新築、旧築の両 方を含む住宅別では、芳香族炭化水素とテルペン類が戸建住宅に比べ 集合住宅では 16.5 倍、17.4 倍濃度が高いという結果となった。

住宅の工法別を比較すると在来工法の HCHO、TVOCの濃度はいずれ も最も低く、続いて工業化住宅、鉄筋コンクリートの集合住宅という 順番であった(表 6 )。

\section{3 冬期と夏期の比較 $\mathrm{HCHO}$ 濃度の冬期と夏期の比較}

冬期と夏期の $\mathrm{HCHO}$ 濃度を比較したものを図 5 から図7に示す。全住 宅では、冬期が夏期に比べ濃度が 1.3 倍高いという結果となった。室 内VOCの発生源として、建材や壁装材等に使用している接着剤が考え られ、夏期は開口部を開けた状態で生活しているのに対し、冬期は開 口部を締め切った状態で生活していることから、室内濃度が引き上げ られたものと考えられる。また、冬期では、室内の開口部を締め切っ

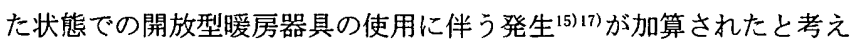
られる。

\section{TVOC 濃度の冬期と夏期の比較}

全住宅の冬期と夏期のTVOC濃度の比は 2.2 倍と HCHOに比べてもそ の差は大きい。TVOCを比較すると冬期の新筑と既築では差が見られな かったのに対し、夏期では新筑と既築の差が大きいことから、冬期は 開口部を締め切っているのと、石油ストーブ等の開放型燃焼器具 ${ }^{15)}$ 17)、芳香剤などによるリモネン、防虫剤による $\mathrm{p}$-ジクロロベンゼン
などの建材以外の発生源が TVOC 濃度に大きく影響していると考えら れる。更に、新築時の冬期と夏期の差は 5 ケ月間の経時変化と季節に よる住宅の開口部の開放頻度による差が影響したと推測される。

戸建住宅における冬期と夏期のTVOCの濃度分布を図8、図9に示す。 冬期は新筑住宅で在来工法、工業化住宅の平均値はそれぞれ 1370 、 $1940\left(\mu \mathrm{g} / \mathrm{m}^{3}\right)$ とSeifert の推奖值に比べ高い值を示した。一方、夏 期は320，580 $\left(\mu \mathrm{g} / \mathrm{m}^{3}\right)$ とやや高い值であった。多くの住宅において Seifert の TVOC 推奖值の $300 \mu \mathrm{g} / \mathrm{m}^{3}$ を超えており、既築住宅において も基準值以下の住宅が少ない事から欧米の諸外国に比べ日本の住宅は TVOC 濃度が高いといえる。

次に、集合住宅における夏期と冬期の TVOC 濃度のを図 10 に示す。 その結果、冬期が夏期の 2.6 倍高い值であった。これの属別のものを 図11、図 12 に示す。これより季節に関わらず全住宅では脂肪族炭化 水素とテルペン類が $500 \mu \mathrm{g} / \mathrm{m}^{3}$ を超えている。ここで、属別の冬期の濃 度を夏期の濃度で除した比を表 7 に示す。これより、全住宅ではエス テル類、ケトン類が冬期に高い。これを、新築と既勧で比較するとほ とんどの属で住宅の築年数に関わらず冬期のほうが濃度が高いといえ るが、唯一既築住宅のエステル類は夏期のほうが高い值となってい る。

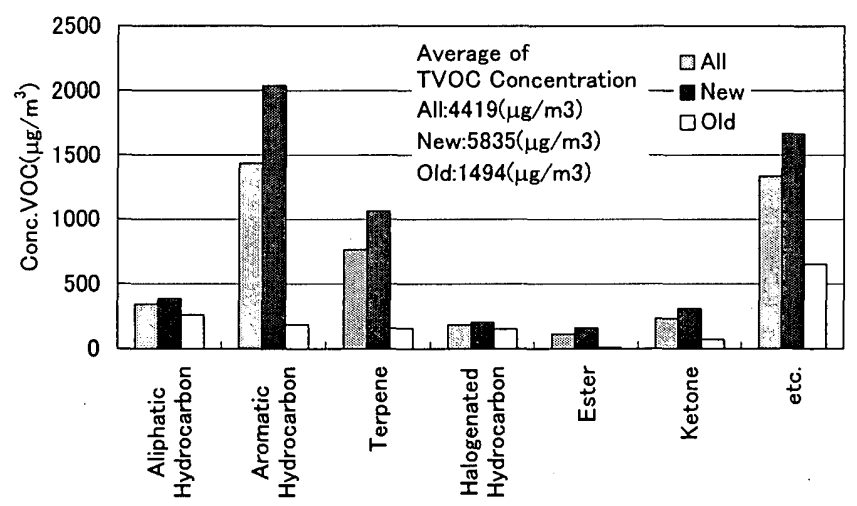

図 11 冬期のVOC 属別濃度

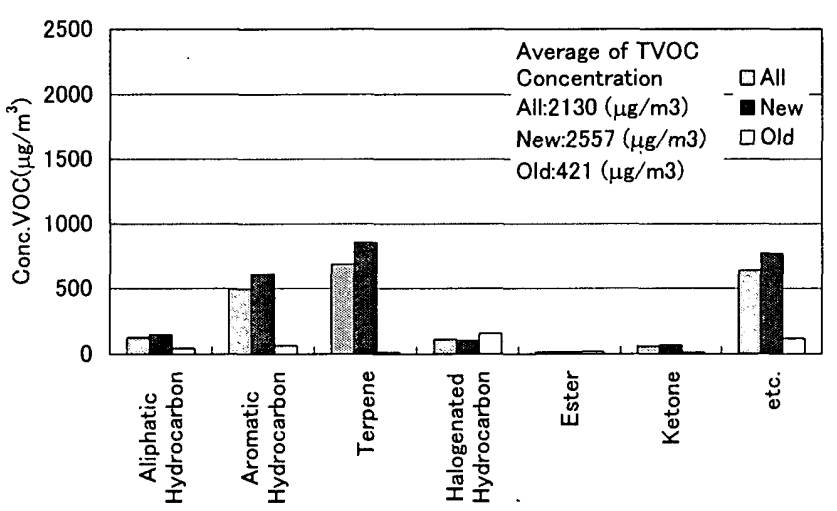

図 12 夏期の VOC 属別濃度

表 7 夏期と冬期の属別 VOC 濃度比

\begin{tabular}{lccc}
\hline \multicolumn{1}{c}{ VOC-Group } & All & New & Old \\
\hline Aliphatic Hydrocarbon & 2.8 & 2.6 & 6.1 \\
Aromatic Hydrocarbon & 2.9 & 3.4 & 3.0 \\
Terpene & 1.1 & 1.2 & 11.9 \\
Halogenated Hydrocarbor & 1.7 & 2.0 & 1.0 \\
Ester & 7.6 & 11.6 & 0.5 \\
Ketone & 4.2 & 4.6 & 7.0 \\
etc. & 3.9 & 3.5 & 8.0 \\
TVOC(n-C6 equivalent) & 2.1 & 2.3 & 3.5 \\
\hline
\end{tabular}




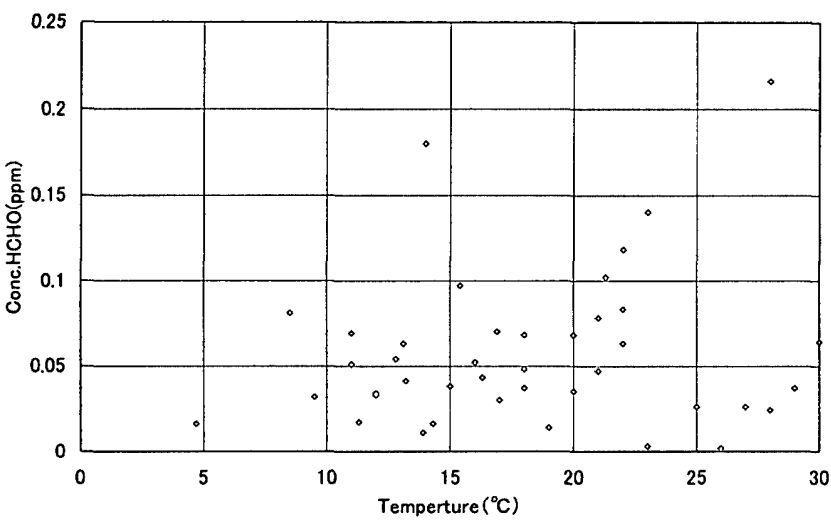

图 13 温度とHCHO 濃度との閶係

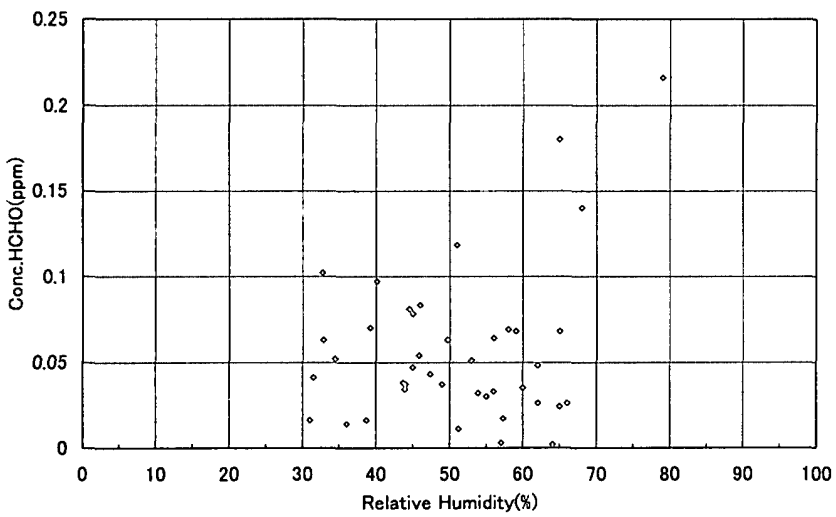

图 14 湿度と $\mathrm{HCHO}$ 濃度との関係

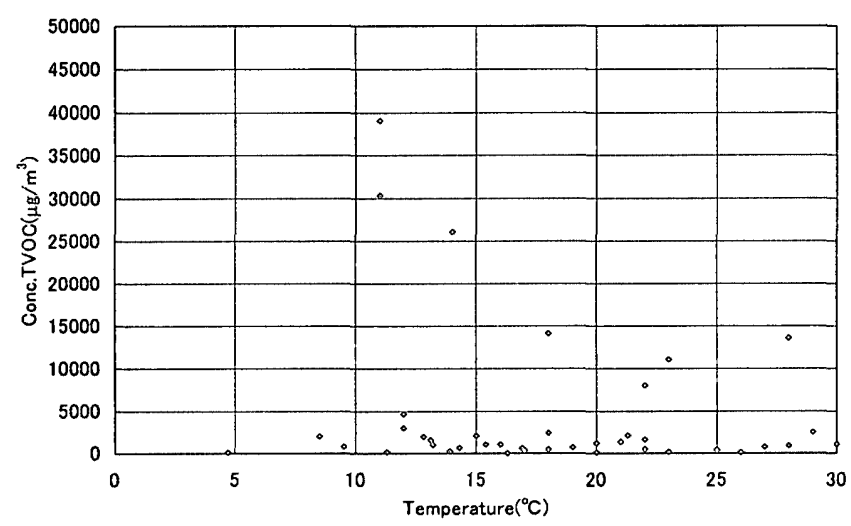

图 15 温度とTVOC 濃度との閶係

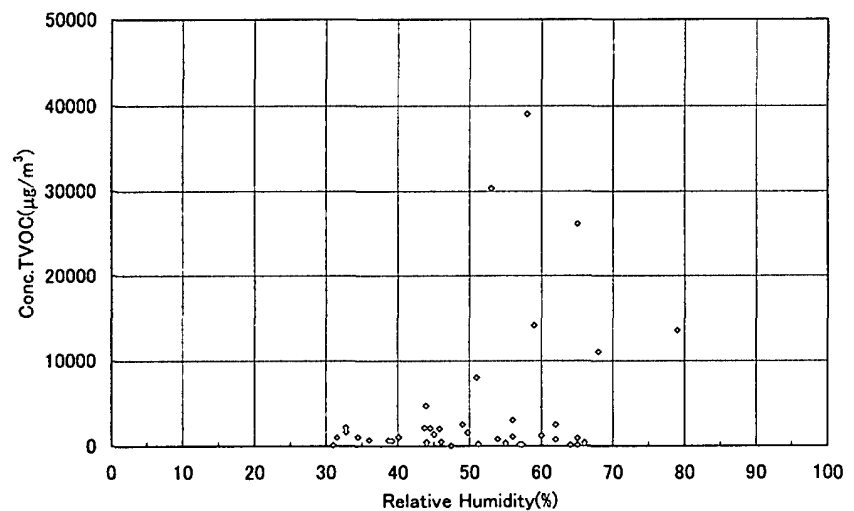

图 15 温度とTVOC濃度との関係

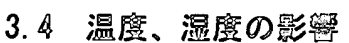

チャンバー実験においては温度、湿度はHCHO、TVOC の放散を促進 することが報告されいる。また、生活が営まれている住宅においては 温度と $\mathrm{HCHO}$ 濃度とに相関がある ${ }^{17)}$ という報告とないという報告の両 方があることより、本調査でも温度、湿度を郡山にて測定を行った (図 13〜16)。その結果、本調査では温度、湿度と HCHO、TVOC 濃度で は相関が確認できなかった。これより生活が営まれている住宅におい ては温度、湿度等の環境因子のみならず、換気の状況や家具、生活用 品などの居住者により室内に持ち込まれものにも左右されると推測さ れる。

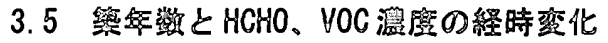

$\mathrm{HCHO}$ と TVOC灙度と築年数との関係を図 17 、図 18 に示す。いずれの 物質も指数関数的な减衰傾向になっている。これをHCHO と TVOCに分 けて検討すると、HCHOにおいては相関係数は $\mathrm{r}=0.50$ であり、住宅内 での HCHO の発生は建物以外の要因も考虑する必要があるといえる。 また、近似式よりHCHOの発生が定常となる筑年数は6年となり、それ までは発生量が減衰し続けることより、建材が HCHO の最大の発生源 であると推測される。更にそれ以後については、居住者により室内に 持ち込まれたものにも大きく影響されることが推測される。

TVOCについても指数関数的な減衰曲線を描いている。相関係数は $\mathrm{r}=0.75$ と高くTVOC 曟度は築年数に大きく依存している。また、近似 式よりTVOC浱度が安定するといえるまでの年数は築後8年という結果 になった。これを物質別に観ると、トルエンがかなり減少しているの に対し、 $\alpha$-ピネンはほとんど減少しないという結果を得た。また、 住宅によっては築年数には係わらず防虫剤から発生したp-ジクロロ

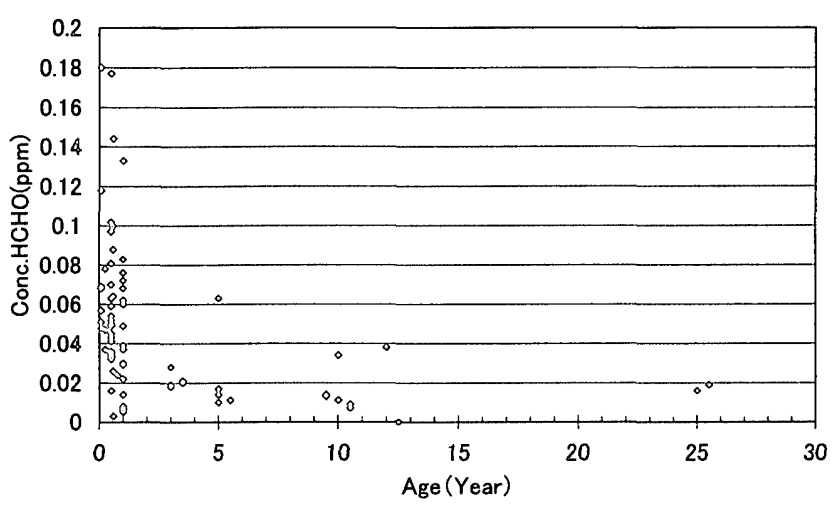

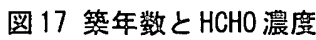

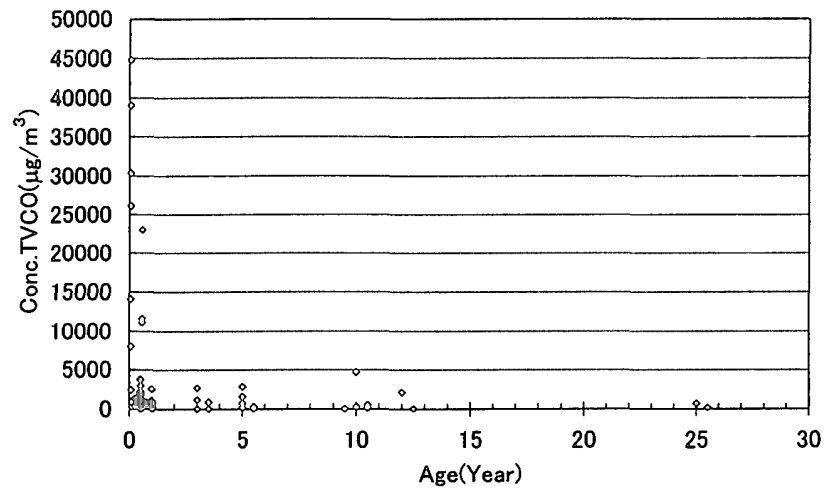

图 18 築年数と TVOC 濃度 
ベンゼンが高い值を示しているものがあった。さらに、筑 5 年である がトルエン、アセトン、p-ジクロロベンゼン、リモネンが高い住宅が あったが、この住戸は半年前に居間と洋室の2室及び床下をカーペッ トからフローリンクにリフォームしており、その影響があるものと考 えられる。

\section{6 入居前と入居直後の HCHO、TVOC 濃度の経時変化}

入居前と入居後 6 ヶ月までのHCHO とTVOC濃度の経時変化を図 19 に 示す。入居前と入居後1ヶ月との濃度を比較すると、HCHOが $39 \%$, TVOC が $17 \%$ に減少している。その後は、経過月により上下する結果になっ ている。これより、施工期間中の放散量が多いことと、入居による開 口部の開閉による換気の増加により、室内の濃度が減少したものと考 えられる。また、HCHO とTVOCでは、减衰率が 2 倍も異なる事より成 分そのものの化学的特性、あるいは発生源の状態により異なることが 推測される。

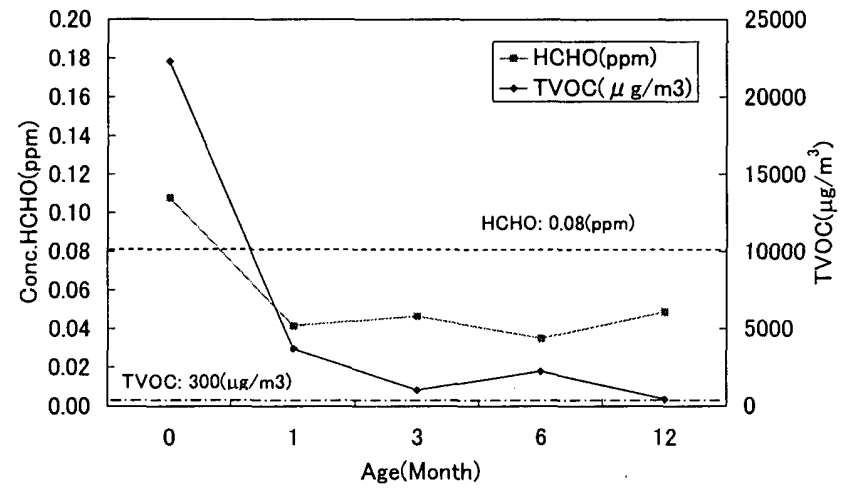

図 19 新築時におけるHCHO、TVOC 濃度の経時変化

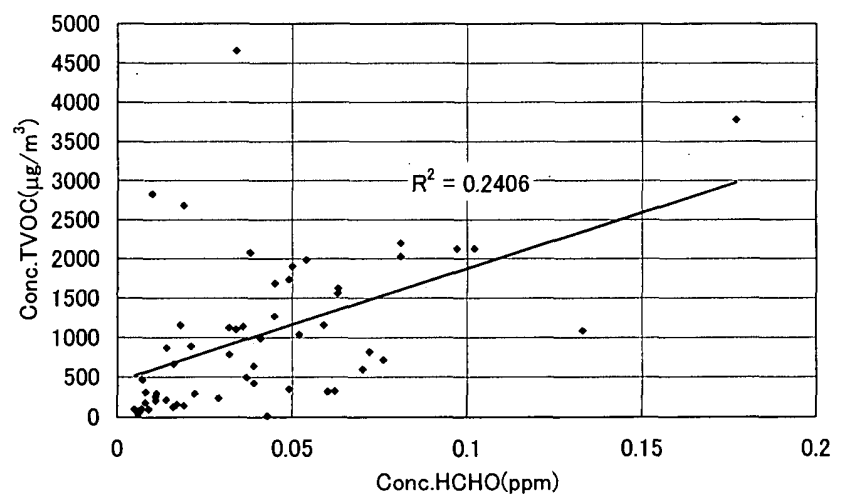

図20 HCHO-TVOC濃度の関係

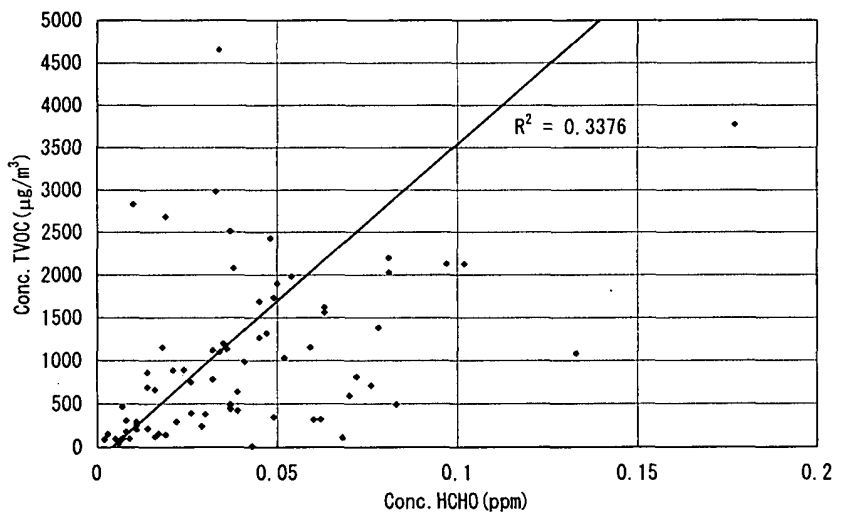

図 21 入居後のHCHO-TVOC濃度の関係

\section{7 HCHO 濃度と TVOC 濃度の関係}

図20にはHCHO とTVOCの関係を示す。HCHOあるいはTVOCのいずれ かが特異な濃度を示すものはあるものの、全体的な傾向としてはHCHO 濃度が高くなるとTVOC 濃度も高くなるものの、特に入居前に高い濃 度を示すものもあり相関係数は $\mathrm{r}=0.4$ と低い值を示した。そこで、建 材による放散が特に多いと考えられる入居前のデータを母集団より除 くと、 $\mathrm{HCHO}$ 濃度と TVOC 濃度の相関係数は $\mathrm{r}=0.58$ となった（図 21 参 照)。ところが、さらに母集団より新築住宅を除いた既築住宅のみの 相関は $\mathrm{r}=0.09$ となることより、住宅の竣工より期間が経つに連れ、 $\mathrm{HCHO}$ と TVOCの放散速度が変化することと、建材以外に起因する $\mathrm{HCHO}$ とVOCが大きく影響すると考えられる。

\section{4. 結論}

本研究では以下の所見を得た。

1) HCHOのサンプリング方法としてパッシブサンプラー法の有用性を 確認した。

2）本調査で測定した住宅の HCHO 濃度の平均は $0.048 \mathrm{ppm} 、 \mathrm{TVOC}$ 濃度 $3640 \mu \mathrm{g} / \mathrm{m}^{3}$ であった。

3）集合住宅のほうが戸建住宅より HCHO、TVOC濃度のいずれにおいて も高い值を示した。しかし、既築住宅での住宅種別の濃度を比較 するとあまり差がないという結果になった。

4）冬期と夏期の HCHO、TVOC 濃度を比較した結果、住宅種別、筑年数 にかかわらず冬期の濃度が高いことが分かった。

5）温度、湿度とHCHO、TVOC 濃度とでは相関が認められなかった。

6）各物質の濃度の経時変化より建材が室内のVOC 濃度を支配する時 期と、生活により室内に持ち込まれる VOC が支配する時期がある ことが確認できた。

7）新筑住宅において入居により HCHO、TVOC濃度の両方が大きく減少 することが分かった。

\section{今後の課題}

本調査より今後の課題として以下の点を上げる。

1) 材料試験の結果と、試験を行った材料を用いた実験住宅において実 測を行い発生源の比較検討を行う必要がある。

2) 室内 VOCのモデル化を行うに当たり吸着・脱着のメカニズムを解明 する必要がある。

3）換気量を把握することにより室内の VOC 発生量を把握する必要が ある。

4) 今後は細かく成分により比較検討を行い住宅によるVOC、生活によ るVOCを明確にする必要がある。

5）環境因子として材料の表面温度を測定する必要がある。

\section{謝辞}

本研究では住宅での調查に当たり林氏(積水ハウス)、鵜飼氏(ミ节 ワホーム)、河合氏 (三井ホーム)、岩崎氏 (大和ハウス)、田中氏 (䇣 和)、田島氏 (エアサイクル産業)、子安氏 (三菱地所ホーム)に多大 なる協力を得た。なお、本研究の実測は、厚生省が財団法人ビル管理 教育センターに委託した「建材・機械等の揮発性有機化学物質に関寸 る調查研究委員会」の研究費によって実施した。ここに記して感謝寸 る。

\section{文献}

1) Krause, Mailahn, Nagel, Schulz, Seifert, "Occurence of Volatile Organic Compounds in the Air of 500 Homes in the Federal 
Republic of Germany", The 4th Int. Conf. on Indoor Air Quality and Climate, Berlin(West), Vol. 1, pp102-105, 1987

2) Molhave, Bach, Pedersen, "Human Reaction to Low Concentrations of Volatile Organic Compounds", Environ. Int., Vol. 12, 167-175, 1986

3) Molhave, "Volatile Organic Compounds, Indoor Air Quality and Health", The 6th Int. Conf. on Indoor Air Quality and Climate, Toronto, Vol.5, pp15-33, 1990

4) Otson, Fellen, Tran, "Investigation of VOCs in Canadian Residences", The 6th Int. Conf. on Indoor Air Quality and Climate, Helsinki, Vol.2, pp141-146, 1993

5) Park, Fujii, Yuasa, Kagi, Toyozumi, Tamura, "Characteristics of Volatile Organic Compounds in Residences", The 7th Int. Conf. on Indoor Air Quality and Climate, Nagoya, Vol.3, pp579-584, 1996

6) Seifert, Schulz, Steinbach, Ullrich, Mailahn, "Seasonal Variation of Concentration of Volatile Organic Compounds in $\mathrm{Se}^{-}$ lected German Homes" , The 4th Int. Conf. on Indoor Air Quality and Climate, Berlin(West), Vol.1, pp107-111, 1987

7) Seifert, "Regulating Indoor Air", The 5th Int. Conf. on Indoor Air Quality and Climate, Toronto, Vol.5, pp35-49, 1990

8) Wolkoff, Cluasen, Nielsen, Molhave, "The Danish Twin Apartment Study Part I: Formaldehyde and Long-Term VOC Measurements" , The 5th Int. Conf. on Indoor Air Quality and Climate, Vol. 2, pp657-662, 1990

9) Hallace, Clayton, "Volatile Organic Compounds in 600 U.S. Homes: Major Sources of Personal Exposure", The 4th Int. Conf. on Indoor Air Quality and Climate, Berlin(West), Vol. 1, pp183-186, 1987

10) USEPA Method 8315A, "Determination of Carbonyl Compounds By High Performance Liquid Chromatography (HPLC)", 1996

11) 池田、松村、堀、木村、”集合住宅における室内空気質寒態調查 (そ の1) HCHOの測定”、第15回空気清净とコンタミネーションコント ロール研究大会, pp373-376, 1997

12)石川、吉澤、松村、"パッシブサンプラーを用いた換気量測定法に 関する研究”，日本建築学会計画系論文集，Vol.467, pp47-54, 1995

13)不村、池田、堀、松村、”集合住宅における室内空気質実態調查 (そ の2) VOCの測定”、第15回空気清浄とコンタミネーションコント ロール研究大会, $\mathrm{pp} 377-380,1997$

14）坂本、岩下、木村、“居住状態の戸建住宅におけるVOC” s, HCHO浱 度調查”、日本建築学会大会学術講演梗概集, pp739-740, 1997

15) 菅原、”燃焼器具により発生するHCHO”、日本建築学会学術講演梗 概集 (近畿)、pp753-754，1996

16）豊住、藤井、湯浅、键、田村、”有機系ガスからみた住宅の空気質 に関する研究”、第 14 回空気清浄とコンタミネーションコント ロール研究大会予稿集、pp161-164，1996

17）野㠃、吉澤、池田、“室内 VOC、HCHO 污染に関する研究（その 1 ）、 開放型石油暖房器具の非メタン炭化水素発生特性 (Part 1) 、日本 建築学会計画系論文報告集 、1999.3

18）堀、楊、”住宅における揮発性有機化合物污染と測定法に関する考 察”、人間と生活環境、Vol. 4, No. 1, pp61-69, 1996

19）松村、村松、亀谷、”室内空気污染に関する研究（第 3 報）、室内 HCHO灙度について”、日本公衆衛生雑誌、Vol. 30，pp303-308，1996

20) 宮崎、岩下、志波、高間，“住宅におけるVOCs 源度の低減を考虑
した空気環境計画に関する研究 その 1 リフォーム前の住宅及び 新筑住宅におけるVOCs渗度測定”, 日本建築学会大会学術瀞演梗 概集, pp759-760，1997

21) 守屋、疋田、東実、新田、“新築住宅における揮発性有機化合物の 実測調㚗第 1 報冬期における揮発性有機化合物の実測調㚗”，空 気調和衛生工学学術講演論文集, pp53-56, 1997

22) 湯浅、藤井、键、潘、“住宅の室内空気質に関する実態調查”、日 本建築学会大会学術满演梗概集, pp743-744, 1997

23）環境庁、“有害大気污染物質測定方法マニュアル”, pp45-46, 1997

24）厚生省、“快適で健康的な住宅に関する検討会議報告書”、pp28、居 住状態における住宅室内の揮発性有機化合物に関する実態調査, 1998 